


\section{Partner Acknowledgements}

Maytree would like to acknowledge the support of Ambassador Peter M. Boehm and his team at the Canadian Embassy in Berlin for identifying some of the German partners and for sponsoring this publication.

\section{Canadà}

Partners

\section{STU스GART}

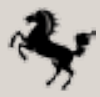

\section{Robert Bosch Stiftung}

\section{HEINRICH BÖLL STIFTUNG}

\section{BertelsmannStiftung}

In cooperation with

Ministry of Labour, Integration and Social Affairs North Rhine-Westfalia

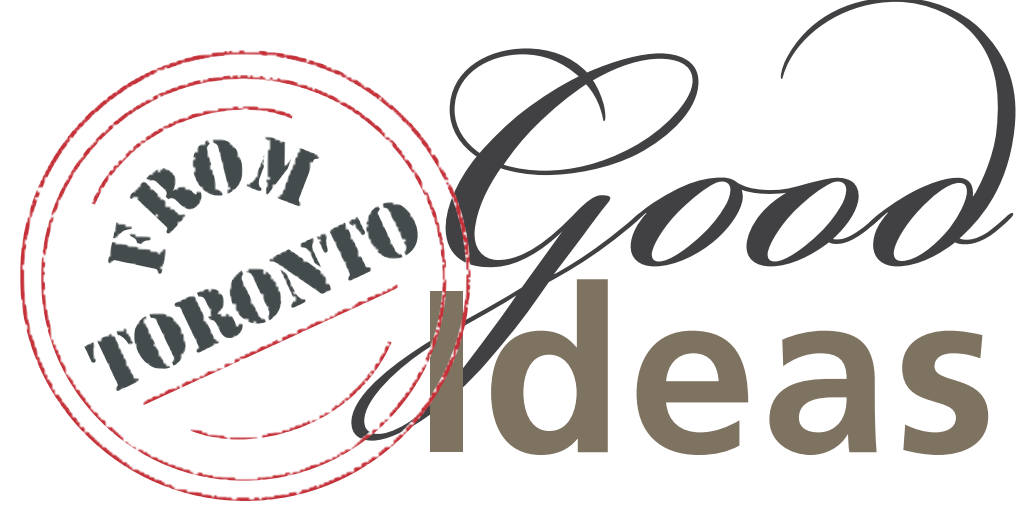

Good Ideas from Toronto: an Exchange of Immigrant Integration Practices

November 28 to December 2, 2011

\section{The Delegates}

Alan Broadbent, Chairman, The Maytree Foundation

Matt Galloway, Host, Metro Morning Show, Canadian Broadcasting Corporation

Elizabeth Mclsaac, Executive Director, Toronto Region Immigrant Employment Council (TRIEC)

Ratna Omidvar, President, The Maytree Foundation

Donna Quan, Deputy Director, Academic, Toronto District School Board Deputy Chief Peter Sloly, Toronto Police Service

Markus Stadelmann-Elder, Communications Manager, The Maytree Foundation

\section{The Cities}

Stuttgart - November 28

Hamburg - November 29

Berlin - November 30 and December 1

Cologne - December 2

Historical context and background on the Canadian experiment

Changing labour market outcomes

Ensuring student success

Winning hearts, minds and market share

Policing for a new demographic

Travelling the world for good integration practices 


\section{Explaining the Canadian Experience}

Since my arrival in Germany in 2008, I have witnessed a growing interest in how integration works in Canada. The Embassy of Canada is pleased to support the Maytree Foundation's "Good Ideas from Toronto" Roadshow. This visit represents an opportunity for practitioners from our two countries to share innovative ideas that can more successfully support the needs of people as they move across the globe and, in particular, into urban centers.

Canada is a young nation built on immigration. Canadians continue to celebrate successes, confront challenges and learn lessons from our long relationship with immigration and integration. This year's Roadshow to Stuttgart, Hamburg, Berlin and Cologne will facilitate the exchange of ideas, experiences and good integration practices on both sides of the Atlantic. In the face of continuing public debate over immigration and integration policies in Germany and elsewhere in Europe, we welcome the Maytree Foundation's efforts to share with their German hosts some of what has worked well in Canada's immigration-integration story.

I would like to congratulate Ratna Omidvar, President of Maytree, for assembling an impressive group of Canadian experts and practitioners to join the Roadshow team. They will share their expertise and best practices in integration, ranging from experiences of local school management and community policing to public broadcasting and local community organizations.

This year's Roadshow would not have been possible without the generous support of the Robert Bosch Foundation, Körber Foundation, Heinrich Böll Foundation and Bertelsmann Foundation. Maytree is also benefiting from a contribution by the City of Stuttgart, a city that is considered by many in Germany as an integration success story.

Cities are overwhelmingly the destinations of choice for immigrants and the welcome these cities provide is key to successful integration and, in the end, vital to their social and economic health. The "Good Ideas from Toronto" Roadshow gives Canadians and Germans a timely opportunity to learn from each other and to ensure that newcomers enjoy the economic, social and cultural benefits that both our countries have to offer.

\section{Aecorroroen}

Peter M. Boehm

Ambassador

\section{Canadà̀}


Cities and urban regions exercise a powerful pull factor on immigrants seeking a better life for themselves and their families. The integration of immigrants, that complex and challenging process of helping thousands of immigrants fulfill their hopes and dreams, becomes then a central feature of successful cities.

Many cities are rising to the challenge. They proactively help immigrants find work, create businesses, own homes and put their children in school. They do this work in innovative ways, often without the support of other levels of government. And while what works in one city may not work perfectly in another, the exchange of information and ideas between cities inevitably leads to greater imagination and capacity to respond. Smart cities know that when integration is done well, it fuels economic growth, spurs innovation and talent renewal, and promotes an open, richer and more inclusive social fabric.

What a wonderful opportunity, then, to visit four great German cities to share some of Toronto's best ideas in immigrant integration, and to bring back some new ideas from Stuttgart, Hamburg, Berlin and Cologne.

In "Good Ideas from Toronto: an Exchange of Immigrant Integration Practices," we are pleased to present to you some of the best integration practices from Toronto. We believe that these practices will excite you, and we hope you will be interested in adapting and replicating some of them to your local context. After all, cities have a unique capacity to learn from each other, regardless of where they are located.
In this publication, you will read about how cities and immigration are key to Canada's future prosperity. How working with businesses can ensure that recent immigrants find employment in their field. How the public education system plays an important role in the integration of immigrant youth and their families. How a public broadcaster has reinvented itself and achieved national success by paying close attention to who lives in the city. And, finally, how the Toronto Police Service has changed itself to reflect the new demographic reality of the most diverse city of Canada.

This exchange of ideas wouldn't be possible without the support of many individuals and organizations. The Canadian Embassy in Berlin encouraged us and partnered with us to organize this tour. Our German partners have spent many hours working with us setting up the events and organizing site visits for us to learn new approaches: the Robert Bosch Foundation and the City of Stuttgart in Stuttgart, the Körber Foundation in Hamburg, the Heinrich Böll Foundation in Berlin, and the Bertelsmann Foundation in Cologne.

Finally, "Good Ideas from Toronto" only works because of the participation of our delegates, their organizations and their willingness to spend many hours preparing for the trip. A big thank you to all who have made this CanadaGermany exchange of ideas possible.

We hope you will enjoy the ideas we're bringing to you. We, in turn, are looking forward to hearing from you and taking some new ideas from German cities home to Toronto.
Ratna Omidvar

President, The Maytree Foundation
Alan Broadbent,

Chairman, The Maytree Foundation 


\section{Historical Context and Background on the Canadian Experiment}

Canada's immigration story ebbs and flows like the great tides, receding in troubled and leaderless times, and flowing strongly during robust periods of nation building by some of our visionary political leaders.

In the early settlement period, the numbers of immigrants arriving to the land that would one day become Canada were remarkably small and influenced by events, such as the Irish Famine and the American Revolution, in other countries. But the War of 1812 between Britain and the United States led a new attitude toward immigration. As the British governors began to mount their defense, the small size of Canadian population was a military liability. As a result the governors at the time began an active campaign to attract immigrants using land grants and other concessions as incentives. To some extent this strategy worked, and it attracted immigrants from Europe and the United States.

It was not until the early 20th century, however, that the first dramatic increase in immigration took place. After officially becoming a country in 1867, Canadian officials began to look at how it could protect the vast and sparsely populated western part of the country. They felt it was vulnerable to the aspirations of American expansionism, or "manifest destiny" which proposed to see the U.S. take over the entire continent. After taking power in 1896, Sir Wilfred Laurier included Clifford Sifton in his national cabinet. In this role he took on a number of tasks for Laurier, but none more famous and long lasting than the great effort to populate the west.

Sifton did two main things as Minister of the Interior. First, he changed the incentives for immigration officers. Rather than being paid a salary, he paid them on commission, on the basis of how many immigrants they could attract. This made them much more ambitious and aggressive in recruiting immigrants.

Second, he mounted a relentless and seemingly ubiquitous marketing campaign. He aimed it at the United States in the first place. There, he knew, were former Canadians as well as a cohort of farmers experienced in cold weather farming, and both would bring hard assets with them from their current farms. Less successfully, he aimed his efforts at British farmers, but most Britains wanted to move to cities which did not yet exist in the West. When he expanded his recruitment campaign to include northern Europeans, he struck pay dirt. Thousands of European farmers settled in the prairies in the first decade of the century.
The City of Toronto: A Portrait of Diversity

In the City of Toronto over 140 languages and dialects are spoken, and over $30 \%$ of Toronto residents speak a language other than English or French at home.

In 2006, the City of Toronto was home to $8 \%$ of Canada's population, $30 \%$ of all recent immigrants and $20 \%$ of all immigrants.

Between 2001 and 2006, the City of Toronto welcomed about one quarter of all immigrants to Canada.

Half of Toronto's population was born outside of Canada, up from $48 \%$ in 1996.

In 2006, half of all immigrants to the City of Toronto have lived in Canada for less than 15 years.

In 2006, more than half of all immigrants living in the City were age 25 and over; $7 \%$ were preschool age 5 and under; $16 \%$ were school age 6 to 14 ; and $22 \%$ were youth 15 to 24 .

47\% of Toronto's population reported themselves as being part of a visible minority, up from $42.8 \%$ in 2001 . 
The City of Toronto's visible minority population increased by $10.6 \%$ since 2001 , and by $31.8 \%$ since 1996.

According to a March 2010 Statistics Canada study, the visible minority population of Toronto could more than double by 2031 .

By that year, the visible minority population could account for nearly $63 \%$ of Toronto's total population, up from 43\% in 2006. It would also represent $43 \%$ of Canada's entire population of visible minority people.

More than three-quarters (78\%) of Toronto's population could be either immigrants or children born in Canada of immigrant parents by 2031.

(Source: City of Toronto, Statistics Canada)
In those target countries, Canada seemed to be everywhere. Accounts of the time said you couldn't pass a lamp post in any rural village without seeing Canadian recruitment posters. It was one of the great marketing campaigns of the time, seemingly everywhere, targeted at rural folk with dreams of a greater future.

To attract immigrants, Sifton made land available either cheaply, or in some cases he provided land free through grants. The railway was expanded to provide dependable transportation of crops to markets, the railway companies were encouraged to free up some of their holdings for settlement, and the new farmers were attended to in any way that would likely lead to their successful immigration.

The success of the program was reflected in the fact that from 1891 to 1902, over three million people arrived. Based on a population of just over five million, this is an extraordinary increase, and one that seemed to be absorbed with equanimity. It would be many decades, and two world wars, before such levels would be achieved again.

During the First World War and in its aftermath, there was very little immigration. Even through the 1920s there was well less than half the numbers of that booming period in the first dozen years of the century. From about 1930-50, immigration was negligible, reflecting the troubled decades of the depression and the Second World War.

Starting in the 1950s, the numbers of immigrants, and Canada's population began to rise again. By the middle of the century, many more immigrants had skills best suited to urban areas, like brick and tile laying, tool and dye making, electrical and mechanical skills, and financial and commercial background and training. Immigration in this period became about growing Canada's urban centres.

The dramatic rise in population in our three main cities from 1950 to the present shows this gravitation.

\begin{tabular}{|l|l|l|l|}
\hline & 1950 & 1980 & 2000 \\
\hline Toronto & $1,250,000$ & $3,000,000$ & $4,650,000$ \\
\hline Montreal & $1,525,000$ & $2,800,000$ & $3,400,000$ \\
\hline Vancouver & 575,000 & $1,250,000$ & $1,950,000$ \\
\hline
\end{tabular}

From about 1950 to 1975, between 100,000 and 150,000 immigrants arrived each year, two-thirds of them from Britain and Europe, and about 10\% from Asia.

Whereas Canada had once done its best to attract people, the country now faced a new challenge: managing the flow of people. In 1967, under the direction of Prime Minister Lester Pearson, Tom Kent developed a point system which evaluated potential immigrants to Canada based on their education, language skills, work experience, and other attributes thought to contribute to successful integration. It served another useful purpose which was to discontinue the practice of selecting immigrants on the basis of their country of origin or ethnic and racial background. 
In the mid 1980s, the number of immigrants jumped to about 200,000 per year, and as a result of the point system the countries of origin had shifted dramatically so that less than $20 \%$ were from Britain, almost half were from Asia, and about $30 \%$ were from Africa, the Mideast, or South America. The "face" of Canada changed in this period, as it is common to say, because almost $80 \%$ of immigrants to Canada after 1980 were visible minorities, a category used to describe those who are not Caucasian or white.

What's more, most immigrants who arrived in this period settled in three urban regions, Montreal, Vancouver and Toronto. The combined increase in population of these three cities (through immigration from other countries and from rural to urban migration) in 50 years is about 6.7 million people. By comparison, the population of Canada increased over the same period by about 15 million. In other words, these three cities accounted for almost $45 \%$ of the country's population growth. Over that same 50-year period, Canada accepted about nine million immigrants, accounting for $60 \%$ of that population growth.

The Sifton era and the era since 1980 have two similarities. First, Canada welcomed high numbers of immigrants both in actual terms and on a per capita basis. Second, immigrants were strategically chosen based on the needs of the Canadian economy. In Sifton's time, the strength and promise of the economy was farming, and his populating of the west led to the development of Canada's wheat industry. At the end of the 20th century and the start of the 21 st, the Canadian economy is based on information and design, the underpinnings of the modern world economy. Our immigrants are being admitted based on their suitability to succeed in this new economy. They have high levels of education and experience in the modern economy, and want to work at such jobs in Canada. Typically, they are coming from cities to cities, contributing to urban diversity and dynamism.

\section{Alan Broadbent}

Alan Broadbent is Chairman and CEO of the Avana Capital Corporation, and founder and Chairman of the Maytree Foundation. Maytree created and continues to fund

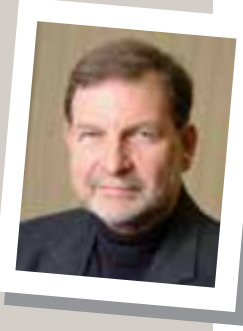
the Toronto Region Immigrant Employment Council (TRIEC) and ALLIES (Assisting Local Leaders with Immigrant Employment Strategies), which facilitate immigrant success in the labour market; and DiverseCity, which is reshaping leadership in society to better reflect the diverse citizens of Canada.

Alan also co-founded and chairs the Caledon Institute of Social Policy (1992); Tamarack - An Institute for Community Engagement (200I); and Diaspora Dialogues (2005), which supports the creation and presentation of new writing that reflects the diversity of Canada.These and other related organizations create and support civic engagement projects to strengthen the public discourse on civil society.

Alan is Co-Chair of Happy Planet Foods; Director of Sustainalytics Holdings B.V.; a Director of Invest Toronto; past-Chair of the Tides Canada Foundation; advisor to the Literary Review of Canada; Member of the Governors' Council of the Toronto Public Library Foundation; Senior Fellow of Massey College and Member of the Governing Board.

Alan is the author of the book Urban Nation, was awarded an honorary Doctor of Laws degree from Ryerson University in 2009, is a recipient of the Queen's Jubilee Medal and Member of the Order of Canada. 


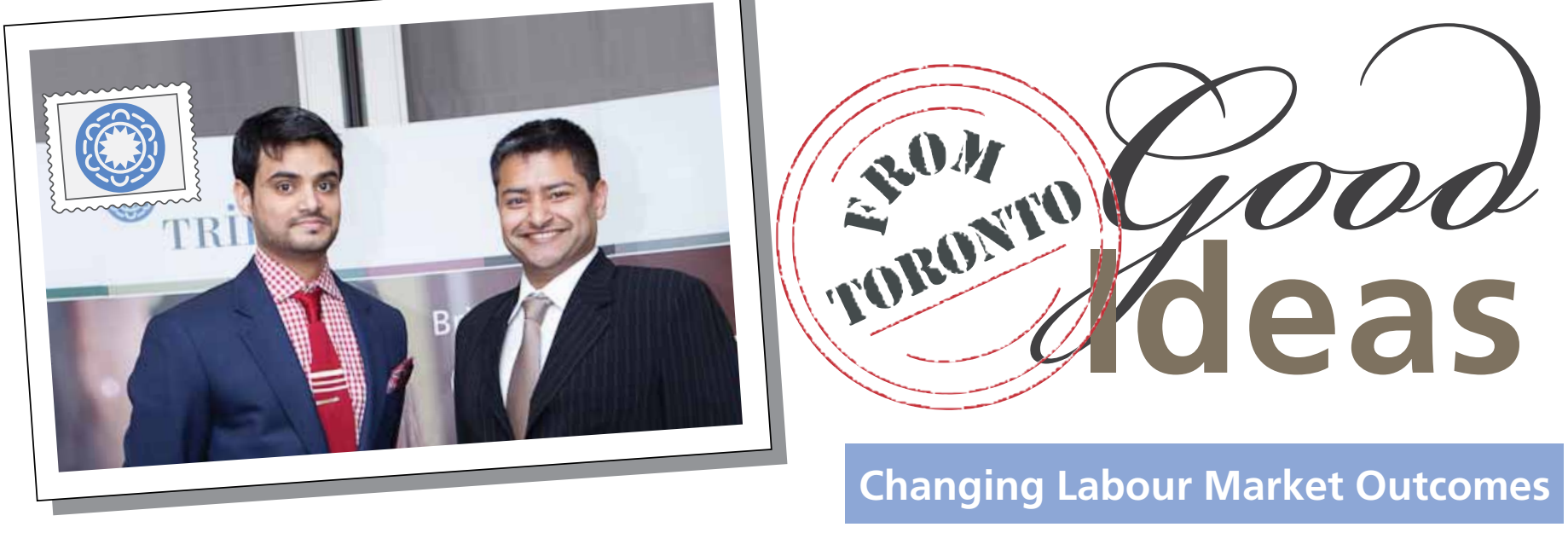

\section{Opening Doors: Gaining industry insights and connections through mentoring}

TRIEC's Mentoring Partnership program brings together recently arrived skilled immigrants and established professionals in occupation-specific mentoring relationships. The relationships focus on working to remove the barriers that immigrants face when entering the labour market while also helping organizations benefit from the talents and skills that immigrants bring with them. Now operating for more than six years in the Toronto region, the program creates 1,000 mentoring relationships between skilled immigrants and established Canadian professionals each year.

Since 2004, over 50 organizations have offered The Mentoring Partnership to their staff as a volunteer opportunity to enhance their leadership and coaching competencies, and develop their cross-cultural skills. Both corporate partners and individual mentors praise the program for its ability to provide these learnings and, ultimately, create change in immigrant integration.

The mentoring approach recognizes that who you know can be as important as what you know when it comes to getting a job. The mentor-mentee relationship is the first link in the development of a professional network that opens doors and changes perceptions about the value of skilled immigrant job applicants.

Relationships are based on the idea of committing "one day of your life" to the program, a commitment of at least 24 hours spread out over a four-month period. During this time mentors help new immigrants navigate through the job search process by sharing their knowledge and experience. The mentor helps to write an effective Canadian resume, to prepare their mentee for an interview and offers advice on how to network. They also provide insights into the Canadian workplace and work culture.

Corporate partners promote the mentoring opportunity internally to staff and identify suitable, qualified volunteer mentors. Community partners match mentors with skilled immigrants and support the mentoring relationship over four months. TRIEC coordinates the program.

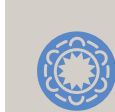

\section{TRIEC Toronto Region Immigrant Employment Counci}

Toronto Region Immigrant Employment Council

Toronto Region Immigrant Employment Council (TRIEC) accelerates the employment of immigrants, relevant to their training and experience, in order to strengthen the local economy. TRIEC brings together employers, regulatory bodies, educators, labour, community groups, government and immigrants to strategize and lead this process. It connects employers to programs that can help them hire better; it educates the public through media and events; and it brings together partners in new and unique ways.

www.triec.ca 


\section{Elizabeth Mclsaac}

Elizabeth Mclsaac

is the Executive

Director of TRIEC.

She has worked

with TRIEC since

it was launched in

2003 as a Maytree

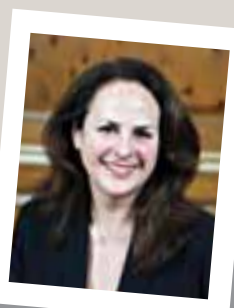

project. She has also held various positions at Maytree, most recently as the director of policy. Before joining the foundation, Elizabeth was the executive director of the Association of International Physicians and Surgeons of Ontario, a nongovernmental organization advocating for policy changes that would create better access to licensing for immigrant doctors. Previous to this, she worked in direct service with immigrant and refugee communities, as well as holding various roles in research and teaching.
ALLIES, a partner program funded by Maytree and the J.W. McConnell Family Foundation, is now working to bring mentoring across Canada. As of summer 2011 , there are ten immigrant employment councils established that provide mentoring programs in ten cities across Canada.

The idea of mentoring has also caught on internationally. In 2007, a delegation from New Zealand's Committee for Auckland travelled to Toronto to learn more about the TRIEC model and its Mentoring Partnership. Mentoring now thrives in Auckland, hosted by Opportunities for Migrant Employment in Greater Auckland (OMEGA).

\section{Contact information}

Melwyn D'Costa, Corporate Partnerships Manager

The Mentoring Partnership

Toronto Region Immigrant Employment Council (TRIEC)

+1-416-944-1946 x 275, mdcosta@triec.ca

170 Bloor Street West, Suite 901

Toronto, Ontario, CANADA M5S 1 T9

www.thementoringpartnership.com

Making it work for you

- Mentoring provides employees with professional development opportunities. Find out whether mentoring programs exist in your organization and, if not, what you could do to start one.

- Look to community organizations that may already be running mentorship programs and collaborate with them for support, leadership and proven programs.

- Position the idea as leadership and cross-cultural competence development. Mentors say that the oneon-one connections with skilled immigrants provide eye-opening insight into their skills and experience, while underscoring barriers faced entering the job market. 


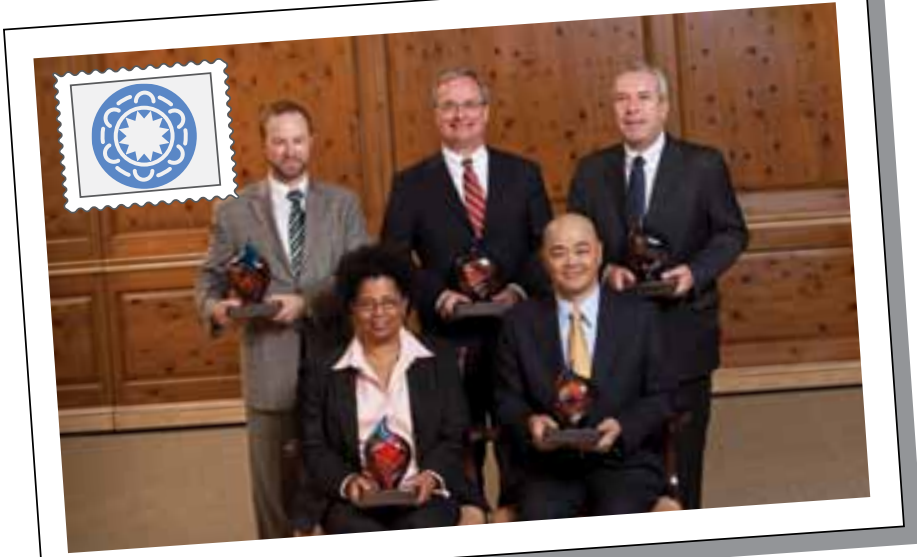

Telling stories of success is an important strategy for building awareness and illustrating how change can happen. In 2004, TRIEC set out to identify the stories of employer success to illustrate to other employers how they can benefit from the skills of immigrants. To find these stories, TRIEC created an awards program with two objectives; first, to identify innovative practices that could be disseminated and replicated; and, second, to recognize and celebrate leadership and innovation among employers.

To date, TRIEC's Immigrant Success Awards have recognized 25 employers and individuals for their leading and innovative practices to better include skilled immigrants in the Toronto region labour market.

Telling the story effectively takes strategic partnerships with media. Over the past number of years, coverage of the business case for the skilled immigrant talent pool has moved beyond the human interest pages and onto the business pages, with more in-depth, practical and positive coverage.

TRIEC's media partners include the country's national broadcaster, the largest daily newspaper, as well as a national human resources publication.

Having a corporate sponsor that both provides resources to the awards program and helps promote it has been a critical success factor. TRIEC is grateful for the support of RBC, one of Canada's largest banks, which has added credibility to the program, as well as providing new channels of promotion to reach small and medium-sized businesses. Itself a pioneering innovator in hiring skilled immigrants and integrating diversity, the bank also hosts the awards reception in its executive lounge lending prestige to the awards event and the program itself.

Through this initiative, TRIEC can showcase companies like Samtack, a relatively small technology distributor, where immigrants comprise $90 \%$ of the workforce. With $\$ 130$ million in revenue in 2009 and $27 \%$ of Canadian market share, the impact of immigrant talent on Samtack's success is clear. Equally telling is the organization's retention rate of $97 \%$.

TRIEC's Immigrant Success Awards, Canada's Top 100 Best Employers for New Canadians and Best Diversity Employers, to name but a few, are all relatively recent recognition programs through which employers seek to gain a competitive advantage over their peers.

Other immigrant employment councils across Canada are also making a point of recognizing leading, local organizations. Employer recognition programs are active in Edmonton, Kingston and Ottawa.

Making it work for you

- Establish partnerships with media outlets to ensure editorial coverage of winners.

- Secure sponsorship from a corporate partner, giving you financial support and adding credibility to your program.

- Always look for new practices to inspire other employers and to make the stories more appealing to media.

\section{Contact information}

Claire DeVeale-Blane, Communications Manager Toronto Region Immigrant Employment Council (TRIEC) +1-416-944-1946 x 271, coleveale@triec.ca

170 Bloor Street West, Suite 901

Toronto, Ontario, CANADA M5S 1 T9

www.isawards.ca 


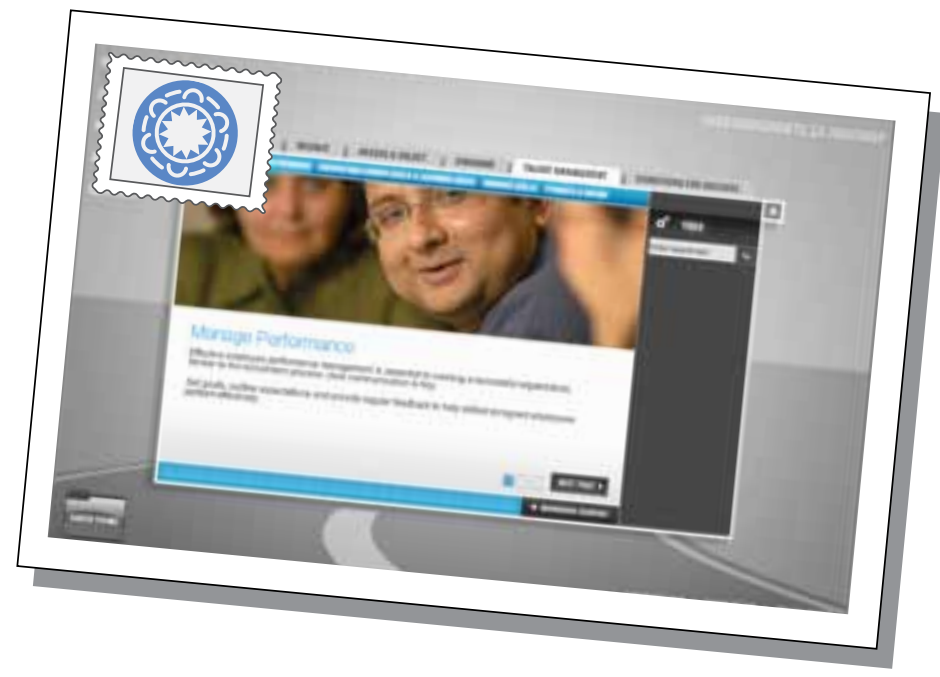

Human resource professionals are often well aware of the value of immigrant talent to business. But they need help to build that awareness in their organizations, and need tools and resources to help them improve recruitment, retention and talent management strategies.

TRIEC has worked with employers to develop and build learning solutions for them. As a first step, it researched "promising practices" among employers that were successful in attracting and retaining top immigrant talent. As more practices, strategies and tools were identified, these were organized and compiled as an "employer roadmap" - a tool to allow employers to explore ideas and examples of practices, following a lifecycle approach to human resources.

As a strategy to reach out and provide learning opportunities to employers, TRIEC also created workshops that used much of the content of the "roadmap" but were delivered by community colleges. As a key curriculum resource to these workshops, TRIEC has developed training videos that address recruiting, integration and cross-cultural teamwork. Two of these videos are dramatic productions that follow one immigrant's journey to finding a job and his experiences in the first months on the job. Each video also comes with downloadable discussion guides. These videos have proven to be valuable resources for immigrantserving agencies offering training to skilled immigrants who are looking to integrate successfully into Canadian organizations.

To make workshops and other resources and learning opportunities more easily available to employers, TRIEC is designing an e-learning platform, and is converting the workshops into a series of online learning modules. This platform will become a clearinghouse of curriculum, resources and training opportunities to support employers and service providers - an employer campus. The campus is based on an open source model for sharing and customization of learning resources, and will include a train-the-trainer model to ensure that resources can be effectively used internally by employers and service providers.

The Employer Roadmap resides on hireimmigrants.ca, a website created by TRIEC and now hosted by ALLIES, a national network of immigrant employment councils. The roadmap has been embedded in websites of three provincial governments and twelve municipalities.

TRIEC's training videos are popular. Available on multiple websites, the videos have been viewed almost 30,000 times and downloaded more than 2,200 times.

Workshops have been delivered to 400 employers. Beginning in 2011, workshops are available to Toronto region employers on a fee-for-service basis, delivered by two local colleges.

\section{Making it work for you}

- Work closely with employers to find out how you can help them with different and innovative approaches.

- Provide easy ways for employers to learn and engage - ultimately, they are the ones making hiring decisions.

- Use a variety of learning tools: videos, case studies, in-person, and online training.

- Find partners to help provide and deliver content.

\section{Contact information}

\section{Rose DeVeyra}

Toronto Region Immigrant Employment Council (TRIEC)

+1-416-944-1946 x 288, rdeveyra@triec.ca

170 Bloor Street West, Suite 901

Toronto, Ontario, CANADA M5S 1 T9

www.triec.ca/find-solutions/for-employers/learning 


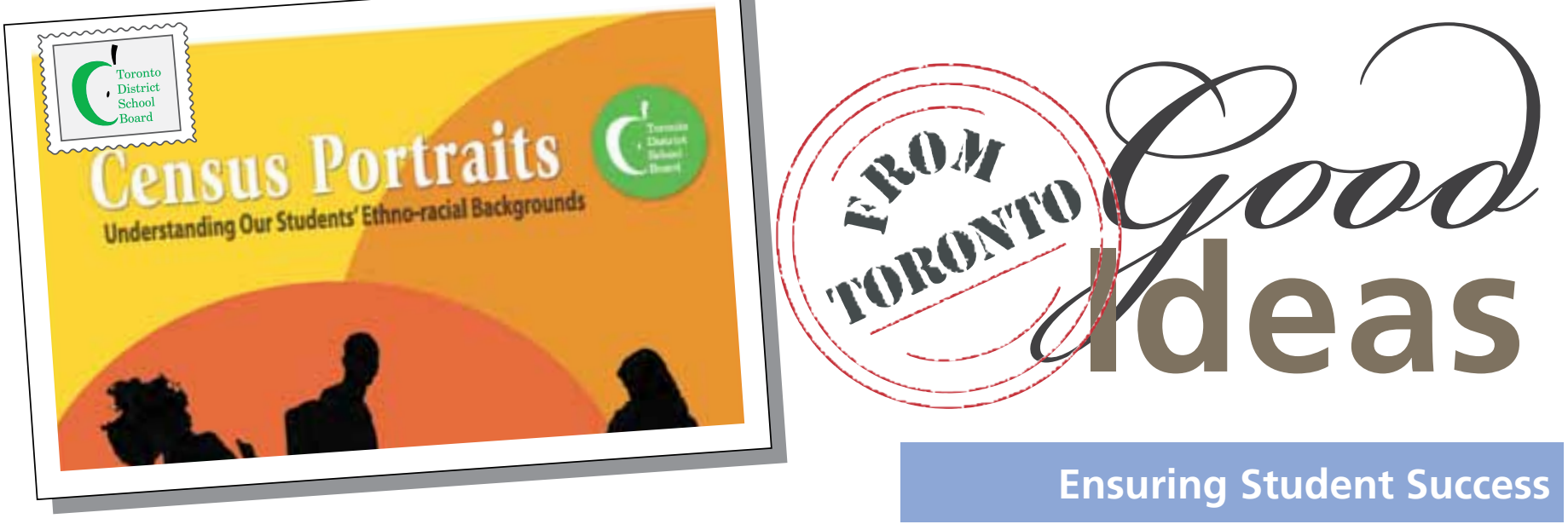

\section{The Student and Parent Census: Using equity-based data to identify student achievement and opportunity gaps}

How can you ensure equity and success for all students? The TDSB uses equity-based data to identify achievement gaps and determine barriers to achievement, to review and implement effective systems, supports and initiatives across the system, and to establish a baseline for measuring improvement over time.

In 2006, the TDSB, in consultation with the Ontario Human Rights Commission and educational experts, developed the Student and Parent Census, a systemwide survey to identify factors within the school system which may inhibit student achievement such as differences in gender, race, ethnicity, mother tongue, income and place of residence.

The questionnaires gather two main types of student information:

(i) demographics (e.g., country of birth, racial background, and socio-economic status) and (ii) student experiences in and outside of school (e.g., school climate, school safety, home support, and extra-curricular activities).

Response rates for the first Student and Parent Census were high, thus allowing useful and reliable data to be reported back to the schools and the system. The information has been used to identify achievement and opportunity gaps, to inform practices, and to improve student success.

One initial challenge was to prepare the relatively newly amalgamated school board and community for this ground-breaking first Census, which included equity-based questions that might be deemed sensitive or controversial by some community members and groups. Conscious efforts were made to secure the support of key staff including union and employee groups, as well as the trust of students and parents. The TDSB was sensitive to questions about family background, human rights, confidentiality and privacy concerns, as well as concerns about the use of the information.

Through the Student and Parent Census, the TDSB has established itself as a leader in the collection of equity-based demographic data. The Ontario Ministry of Education, other school boards in the province, as well as organizations working in

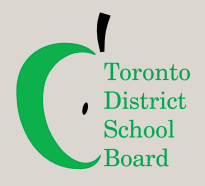

\section{Toronto District School Board}

The Toronto District School Board (TDSB) is the largest school board in Canada and one of the five largest in North America. With close to 600 day schools, it serves approximately 259,000 elementary and secondary students in the regular day school system. The board has been recognized as one of the most diverse in the world, with over 75 languages represented.

TDSB's goal is to create and sustain high levels of excellence for "all" students. A key priority is to close the achievement and opportunity gaps: the gaps between where students are at any given time, and the highest levels that they can potentially achieve. Within this context, the "Opportunity Gap Action Plan" is concerned about the achievement gap in relation to racialized groups of students and students disadvantaged by poverty. www.tdsb.on.ca 


\section{Donna Quan \\ Donna Quan is \\ Deputy Director, \\ Academic in the \\ Toronto District \\ School Board. \\ She provides \\ leadership for the \\ Academic "learning for all" agenda \\ for approximately 260,000 \\ students from Kindergarten to \\ Grade 12.}

Working with staff, Donna provides and enables leadership for Teaching and Learning, Inclusive Schools, School Improvement, Focused Intervention \& Program Supports, Special Education and Section Programs and Information Communication Technologies.

Donna has held a variety of progressively influential positions, including Executive Superintendent with responsibility for 12 Families of Schools and the School Improvement, Effective Schools portfolio and System Superintendent roles in Safe and Caring Schools, Alternative Programs and Schools, Inner City and Information Management. Donna is passionate about Inclusive and Equitable education and is a strong advocate of progressive practices to narrow the opportunity and achievement gaps of students.

\section{Contact information}

\section{Donna Quan}

Deputy Director, Academic Toronto District School Board 5050 Yonge Street Toronto, Ontario, Canada M2N 5 N8

Donna.Quan@tdsb.on.ca www.tdsb.on.ca the health sector, have sought out the Board's expertise as they embark on their own initiatives with demographic data collection.

After considering the value of the data from the first Student and Parent Census, the Board has decided to conduct its Census every five years. The TDSB is currently in the midst of administering the second Student and Parent Census this school year.

Visit the TDSB's website at www.tdsb.on.ca/studentcensus to learn more about the positive impact of the Student and Parent Census.

\section{Making it work for you}

- Leadership is essential. Ensure that the political will of senior decision-makers is in place.

- Consult broadly across the community and with experts. Be sure to address any concerns to build school and community support.

- Work collaboratively with all stakeholders.

- Address privacy and confidentiality issues.

- Design appropriate data collection tools and methods to strive for high return rates.

- Report results to allow effective use of the information as per your organization's stated goals. 


\section{Community and Faith Walks}

The TDSB was looking for a way to support educators in being responsive and relevant in their teaching practices by bridging any gaps between the home, school and community. One successful way was the introduction of Community and Faith Walks. Teachers in some of Toronto's inner-city schools have been participating since 2008.

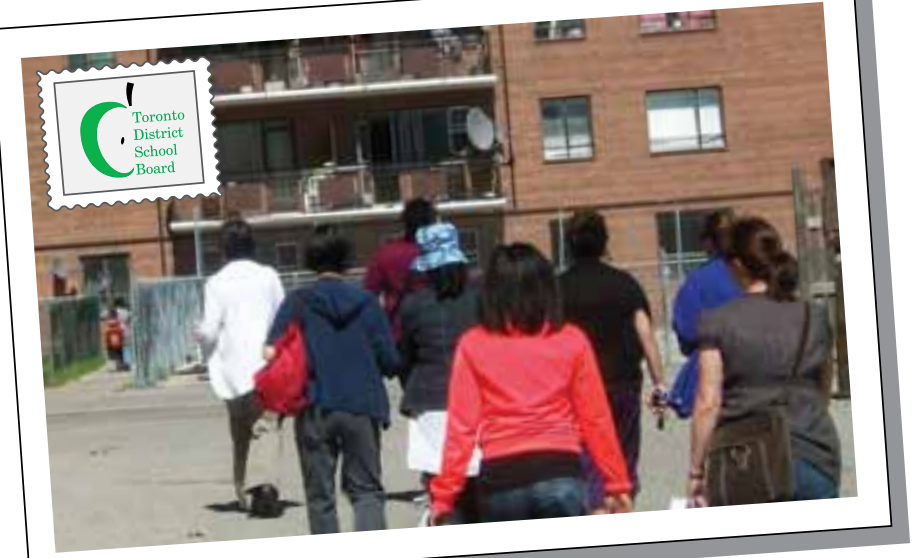

The walks are preceded by a framing session that supports the unpacking of biases, and are followed by a debriefing session that facilitates sharing, consolidates learning and supports next steps.

Community Walks: Educators in Toronto's inner-city schools often live in communities other than those they work in and may not be aware of the variety of lived experiences of the students they teach. Community walks help them see the beauty, challenges, and possibilities of each community as well as the resources available to families and students. They provide teachers with tools and firsthand experiences in creating curriculum and learning environments that are culturally responsive and locally relevant. Participants visit local community agencies, nearby parks, grocery stores, apartment buildings, daycares, and health centers.

Faith Walks: Faith can play a crucial role in a child's development and learning experience. Educators must be aware of the religious diversity in their schools to support the creation of practices that honour and value this diversity. Participants of Faith Walks visit places of worship such as mosques, temples, churches, and synagogues, and speak with religious leaders about supporting students of that faith in a pluralistic education system.
"Going on a Community Walk and debriefing with my colleagues brought about the understanding that there are limited spaces for students in the inner-city to play in a safe environment," explains Bruce Currie, MSIC Teaching and Learning Coach. "So, we really need to make sure that we are supporting daily physical activity and allowing children an opportunity to demonstrate their learning through bodily-kinesthetic activities and not simply pencil and paper."

After going on a Community or Faith Walk, many teachers have changed their curriculum and instructional practices to be more reflective of the students' lived experiences. Administrators have questioned and revisited their school goals and budget decisions as a result of this experience. Several parents have expressed increased trust and faith in schools where educators participate in these events.

"I felt proud to see all these busy people coming to our home; I gave them a speech about how Bengali families run," said Mr. Mujib, parent at George Webster Elementary School.

There has been a steady increase in the number of Community and Faith Walks since 2008. In 2010-2012, administrators and teachers from 15 schools attended a "model" Community and Faith Walk that they then replicated back at their schools. Currently, all staff members in the Model Schools for Inner Cities program, serving schools in high priority neighbourhoods, are being trained on the process and are using this awareness to support innovative teaching, supporting children's well-being and parent and community engagement.

Making it work for you

- Ensure commitment to equitable and inclusive practices at all levels of a school board.

- Position students, parents, and community/religious leaders as the experts.

- Meet with community members, religious leaders and parents prior to the walks to ensure that all stakeholders are aware of their purpose.

- Allow for time to frame the discussion (with a focus on strengths-based learning as opposed to deficit thinking) and time to debrief. 


\section{Hearing and Vision Screening}

Families in high priority neighbourhoods, many of them newcomers, often find it difficult to access health care for their children. Barriers include a lack of medical insurance coverage, lack of accessible transportation, inability for parents to take time off from work, lack of family financial resources to follow interventions prescribed by health care providers, and a lack of confidence in navigating the health care system due to cultural and language barriers.

Therefore, many children may be going to school with undiagnosed and untreated health issues that prevent them from learning to the best of their ability.

As the need became evident and concerns were raised

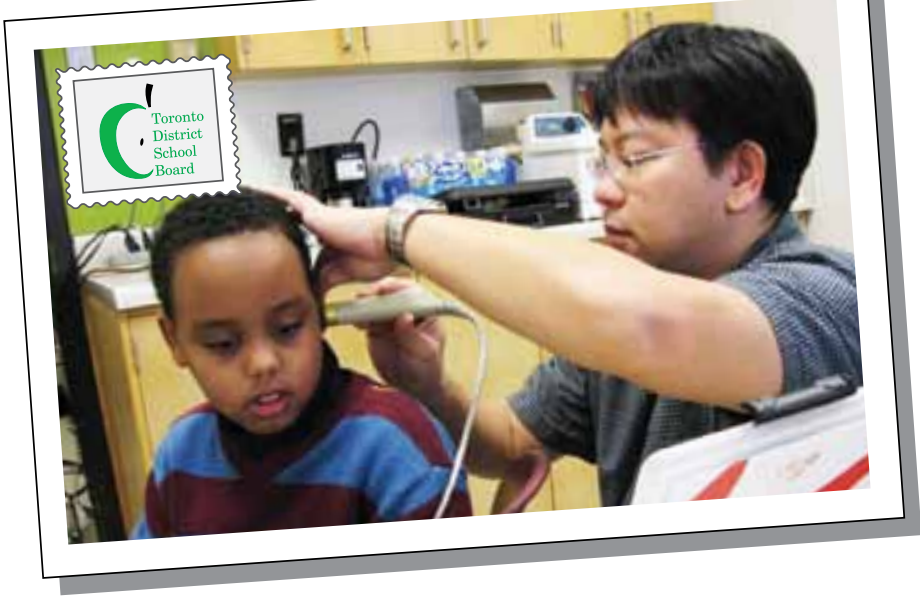

by teachers, principals and parents, a pilot project was established in the Parenting and Family Literacy Centres. With the help of the Toronto Foundation for Student Success (TFSS), financial and in-kind supports were secured from philanthropists and private institutions to allow the program to be expanded into schools and to have tens of thousands of selected students in high needs communities have their eyesight and hearing checked by health care professionals from the Canadian Hearing Society and by immigrant doctors who were seeking accreditation in Canada.

"This is a fantastic initiative to help level the playing field for our inner city children in order to help them reach their full potential," explains a Model Schools for Inner Cities Lead Teacher. "Students have access to formal eye exams and the opportunity to receive a free pair of glasses.

Parents are grateful for the early detection and feel that their child's medical needs are supported. They also are learning to navigate the Canadian health system." neighbourhood schools have received selected vision and hearing procedures in the school locations. Parents were then notified that their child had been identified as having a possible vision or hearing problem to facilitate further examination by a specialist. Follow up procedures were set up so students could receive appropriate care and be given free glasses and hearing aids as required.

This integrated initiative has delivered a key service to a vulnerable population in a trusted part of their local community (i.e., their local neighbourhood school). What's more, students who had been identified with a history of low academic performance or had been referred to Special Education programs were able to be enrolled into "regular" mainstream classrooms.

Next steps for the project include procuring universal screening, inspiring policy change and obtain permanent, stable funding. The Toronto District School Board is requesting government funding for a three-year vision and hearing screening clinics program for its expanding number of Model Schools for Inner Cities which services up to 60,000 students.

This initiative could further be expanded to include other important healthcare and infection prevention measures, including immunizations, TB tests, and newborn care.

Making it work for you

- Provide opportunities for foreign trained medical professionals to gain local work experience through working in positions of visions screeners and program administration when possible.

- Connect school based vision and hearing screening to immediate follow-up services offered in the community to ensure that students don't fall through the cracks or fall further behind.

- Pilot projects with funding and in-kind support from nontraditional sources can jumpstart broader initiatives with more stable funding in school boards. 


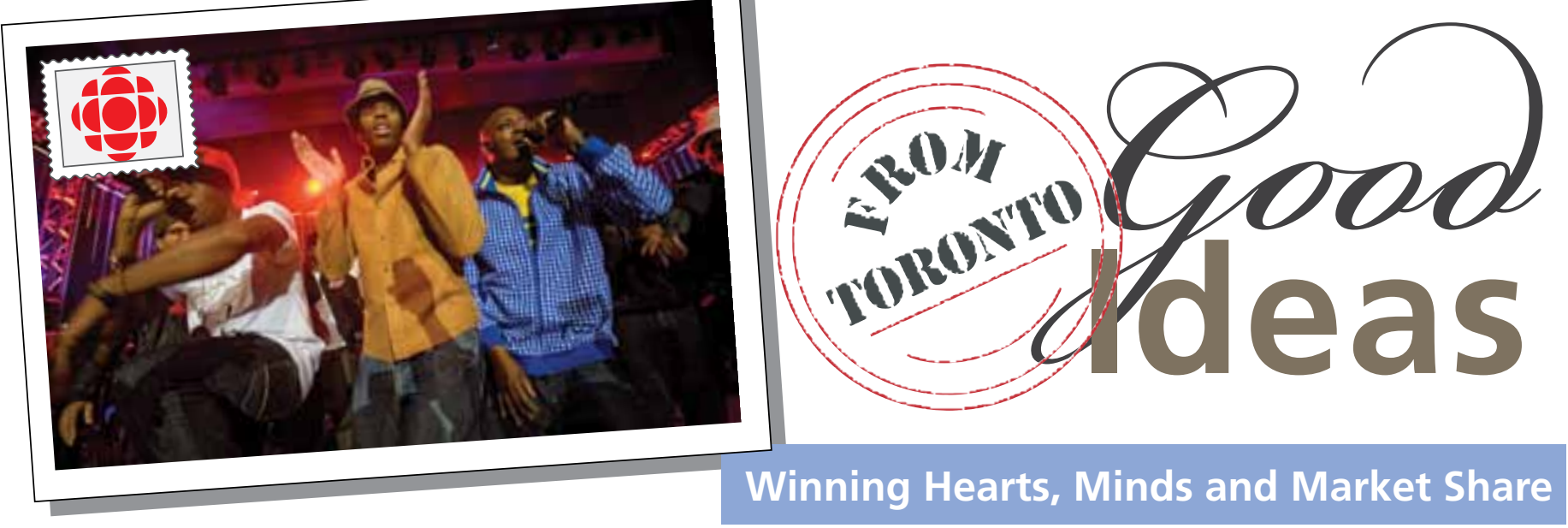

\section{Bringing Hip Hop to the CBC - new audience, new music and a new CBC identity}

Hip hop music and culture have been a vibrant part of Canada's national fabric for more than 25 years. To pay tribute to this unique contemporary art form, the CBC launched the Hip Hop Summit - a month-long celebration in partnership with Manifesto Community Projects (Che Kothari) and Northside Hip Hop (Mark Campbell), with project mentor broadcaster/author Dalton Higgins and project advisor/MC Adhimu "Mindbender" Stewart.

The Hip Hop Summit was an unprecedented and historic event for the community - bringing together the biggest names in Canadian hip hop all performing on one stage. A special live taping of the March 29, 2011 concert brought powerhouse hip-hop stars together: k-Os, Kardinal Offishall, SHAD and many more. This concert was broadcast on several platforms including CBC Radio 1, Radio 2 and Radio 3 , and made available through videos on the Radio 2 website.

The $\mathrm{CBC}$ also threw open its doors and hosted the live event in its headquarters in downtown Toronto. On April 1, 201 1, The Hip Hop Summit held a free, day-long public celebration in the Barbara Frum Atrium of the CBC Broadcasting Centre in Toronto. Over 5,000 people attended the all-day event, featuring breakdance and street dance, hip hop, live visual arts, beat box, turntablism, and panel discussions focusing on the evolution of Canadian hip hop, issues of the past, the current landscape and a look to the future.

By working in partnership with strong local organizations, the $\mathrm{CBC}$ was able to reach out to a whole new audience. As the $\mathrm{CBC}$ has not been traditionally known as a place for the urban music scene, to be able to effectively and credibly deliver on the Hip Hop Summit, CBC brought partners to the table who could reach out and connect with young hip hoppers.

Through innovative outreach and social media marketing, a whole new generation was introduced to the $\mathrm{CBC}$ - and were prominently featured in $\mathrm{CBC}$ Radio programming. Bringing new faces into the $C B C$ is crucial to ensuring that the broadcaster belongs to all Canadians. The Hip Hop Summit provided the platform for bringing hundreds of young Torontonians together. It also exposed traditional CBC audiences to the Hip Hop scene.

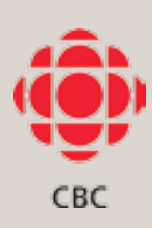

CBC

CBC/Radio-Canada is Canada's national public broadcaster and one of this country's largest cultural institutions. Through the delivery of a comprehensive range of radio, television, Internet, and satellitebased services, CBC-Radio/Canada is available how, where, and when Canadians want it.

www.cbc.ca 


\section{Matt Galloway}

Matt Galloway is the host of CBC Radio One 99.I's Metro Morning, Toronto's top rated morning show.

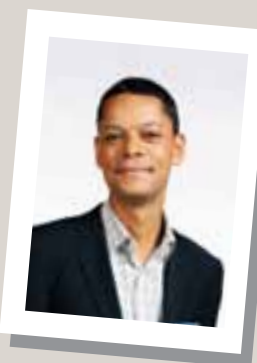

Matt has been working at $\mathrm{CBC}$ Radio for over 10 years and has hosted many programs including The Current, Sounds Like Canada, The Roundup, The Arts Today, and Global Village.

From 2004-20 I0, Matt hosted Here \& Now, the drive-home program heard on CBC Radio One in Toronto and across Southwestern Ontario.

Prior to joining the $\mathrm{CBC}$, Matt studied English Literature at York University and wrote for the Toronto weekly newspaper NOW Magazine.

Matt lives in the west end of Toronto with his partner and their two daughters. He is a member of the Boards of Directors for the Stop Community Food Centre and the Toronto Arts Council.
The month long celebrations generated incredibly original programming for the CBC; a special documentary, Love, Props and the T. Dot: Toronto's Hip Hop History, aired on CBC Television; the March 29 concert was broadcast on CBC Radio 2, and available on the cbc.ca website. This programming serves as an incredible legacy gift to the emerging Hip Hop scene, a community that does not often get enough media play.

I never dreamt that I would see Hip Hop and CBC in the same sentence! - Ken Clarke, Facebook comment

\#cbchiphop"\#cbchiphop summit was incredible; definitely felt like I was part of something special. - Twitter comment

\#cbchiphop"\#cbchiphop underway! Awesomeness in the CBC atrium.

Building relationships and trust with new partners, connecting to new audiences by reaching out directly to them and featuring their stories has been a successful way to integrate diverse and underrepresented voices with the public broadcaster.

\section{Contact information}

Ann MacKeigan, CBC Radio 2, Network Producer

+1-416-205-3782, Ann.MacKeigan@CBC.CA

Emily Mills, CBC Toronto, Senior Communications Officer

+1-416-205-7512, Emily.mills@cbc.ca

$\mathrm{CBC}$

PO Box 400 Stn A

Toronto, Ontario, CANADA M5W IE6

CBC Website: www.cbc.ca/toronto/community/hiphop.html

CBC Radio 3 Website: www.cbc.ca/hiphop

Video of the summit: $w w w . y o u t u b e . c o m / w a t c h ? v=6 \mathrm{~g} 8 \mathrm{swm} \times 67 \mathrm{ro}$

\section{Making it work for you}

- Be willing to try new methods to build and foster new audiences.

- Use the expertise of your partners - this brings integrity to the work.

- Reach out to new audiences and ensure that current audiences can learn from each other. 


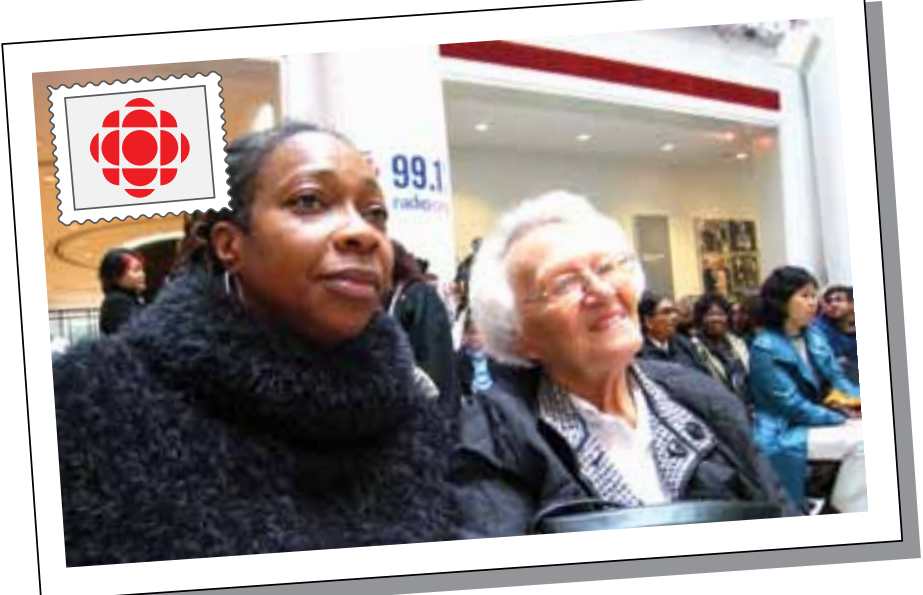

Metro Morning is Toronto - its face, places, voices, stories and music: connecting people, neighbourhoods, communities, diverse pockets and populations. The program expresses the realities of life and experience in Canada's largest city through a weave of news, current affairs and the information you need to start your day, including consistent and predictable weather and traffic.

Today, Metro Morning is the top-rated weekday morning radio show in the city. Many in Toronto consider it essential listening: "If you want be in the know, you have to listen to the show." To achieve this level of success, Metro Morning had to undergo a major transformation.

In 2001, CBC Toronto took a hard and critical look at its shows, even with strong audience numbers. Its typical morning listener was older and not diverse. New listeners were not tuning in, and feedback was that the CBC was "for old, white males." CBC knew that the face of the city had dramatically changed - and if it was going to remain relevant to Toronto residents, it would need to look and sound more like the city. Metro Morning set itself this goal: "do we look and sound like Toronto today?" It had to undergo significant changes - and set about this path by taking a number of steps.

First, Metro Morning built the case for why it needed to change - the demographics and the audience research provided the evidence. The research identified and statistics showed that nearly half the city was made up of diverse communities including large communities of South Asian, Filipino, Chinese, Carribean/African, and Hispanic residents. The next step was to do a gap analysis - which led to editorial choices that needed to be made to reflect these communities. To achieve this, a key element was to build a team that could better reflect Toronto. With strategic hiring and increased diversity, the content and the programming were strengthened. Metro Morning was determined to change the ideas at the story meeting table, by expanding the range of perspectives in the room. Stories were told through an abundance of perspectives including many communities, but always tied back to universal human experiences. Inclusion became a key value for Metro Morning and CBC Toronto.

To make sure that these directions made sense, CBC began to establish and build support and relationships by working with communities. Through editorial panels and consultation with community leaders, CBC became a trusted partner to these communities. The strong relationships with communities have been critical to the success of the program - and have helped shape content and editorial direction.

The transformation of Metro Morning was not an easy one. In the first three months of the new Metro Morning, the audience numbers dropped. But, after the first year, the show became the top-rated show in the Toronto market for the first time in CBC's history. Since 2003, it has been number one 36 times in its rating and received countless awards. It has also doubled its audience of 35-49-year-old listeners.

Metro Morning is often cited as a best practice for change management, and has provided important lessons on how incorporating diversity can pay off.

Making it work for you

- Find a champion, engage the community and build the team.

- Sell the vision and sell the why.

- Research/demographics - understand your audience.

- Implement your program mission and values, including diversity.

- Embed expectations measurements into the performance management of leadership.

- Externally develop partnerships in key communities for deeper relationships.

- Celebrate successes, encourage feedback and communication. 


\section{Contact information}

Susan Marjetti, Managing Director, CBC Toronto

+1-416-205-5791, susan.marjetti@cbc.ca

Joan Melanson, Executive Producer, Metro Morning

+1-416-205-5822, joan.melanson@cbc.ca
Kim Clark, Director, Inclusion \& Diversity

+1-416-205-7388, kim.clark@cbc.ca

CBC Metro Morning website: www.cbc.ca/metromorning Good Idea on Cities of Migration: www.citiesofmigration. ca/good_idea/listen-up-the-business-case-for-diversity

\section{Soccer Nation: How sports can bridge and connect to diverse communities}

Around the globe, hundreds of thousands of people fanatically follow their national soccer teams. The world's greatest game brings and unites soccer fans - as one of the great connectors, sport plays an important role in many communities. $\mathrm{CBC}$ took full advantage of the recent FIFA World Cup in South Africa, in 2010, and brought thousands of Torontonians together to celebrate.

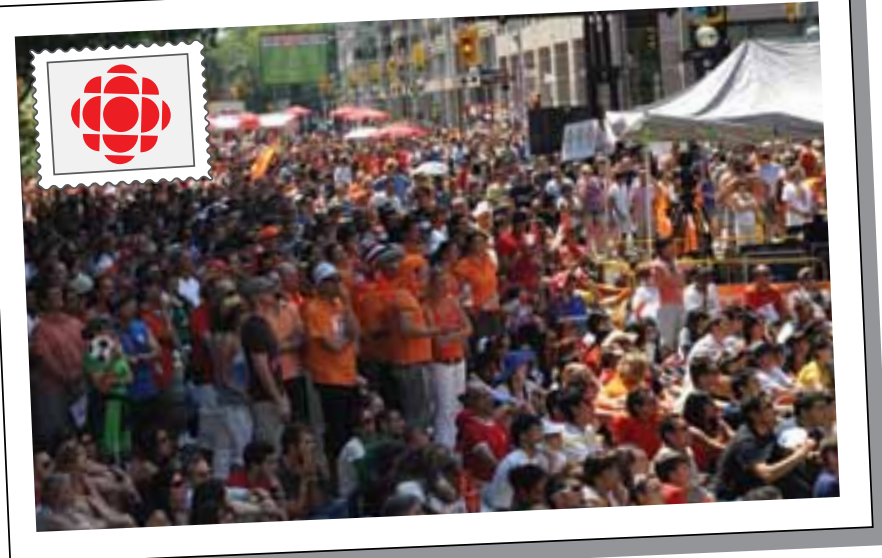

Based on recent research about media consumption of ethnic Canadians, CBC gained a better sense of the kinds of sports programs that ethnic and new Canadians watched. It learned that soccer and hockey were rated as the top two sports for ethnic Canadians, with soccer slightly edging out hockey in popularity. This would not be the case for Canadians in general, where hockey is clearly the number one sport.

Because of this, CBC launched and profiled special programming - Soccer Nation - and this was a fantastic opportunity to connect with its diverse audiences. As the world was captivated by the FIFA World Cup, residents from Toronto's diverse communities came out to cheer on their favourite teams and to celebrate the beautiful game of soccer. Over two days, CBC hosted the city on its doorstep and in the Barbara Frum Atrium. With live play-by-play coverage, and an all-star musical line-up, this was a public event for all Torontonians attended by over 30,000. At the event, community members had the chance to participate in a number of activities including soccer skills and drills, "You be a broadcaster" and to listen to the special $C B C$ radio live concert. A highlight from the event was that many lower-income families and children had the chance to try soccer, to take part in soccer clinics with elite athletes and experts and to get access to free equipment.

Sport is an incredible vehicle for reaching new viewers. Soccer in particular is so well loved across many cultures and countries, and the diverse population of Canada has really added to the growth and popularity of the event by creating enthusiasm and excitement that has been felt coast to coast. In Canada, the Canadian Soccer Association reports that over 1.5 million Canadians are registered as players (2010, Annual Report).

Sports television is a wonderful example of how people become heavily involved in an event. And soccer truly is the "World's Game." Using this vehicle to help integrate and connect diverse communities has been incredibly successful. During the Soccer Nation programming, at least half a million viewers tuned in to watch each game - and some games had over a million viewers. Soccer Nation, and the sports broadcasting became the topic of public conversation, connecting and bringing together communities across the country.

\section{Contact information}

Joel Darling, CBC

PO Box 400 Stn A, Toronto, Ontario, M5W IE6

cbcsoccernation.com

\section{Making it work for you}

- Bringing people together and creating special moments for celebration creates real opportunities for social cohesion.

- Find a vehicle that has universal appeal.

- Provide an opportunity for individual communities and groups to showcase their event, tell their stories, and reveal their local heroes. 

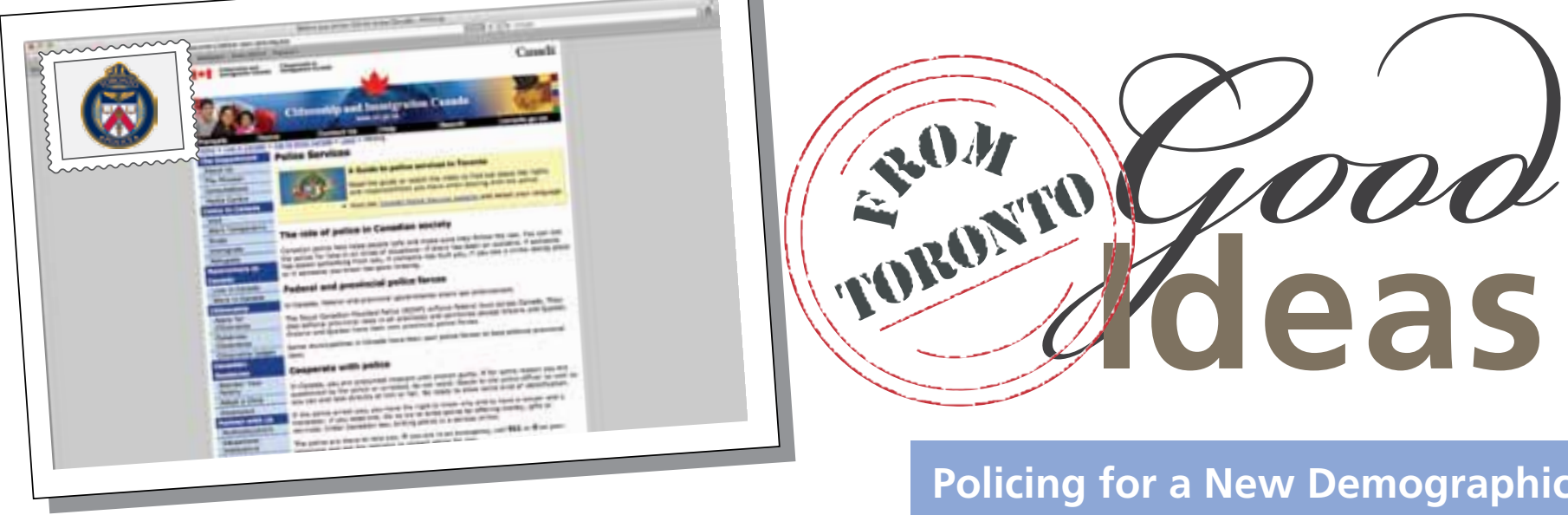

Policing for a New Demographic

\section{Earning Trust: Newcomer Outreach Program}

Since the local police force is one of the most visible institutions in any city, it is important that a newcomer's first contact is a positive one.

"We have a community of people who have come from all over the world, who speak every language, practise every faith and who are part of every culture," explains Chief Bill Blair. "Part of our responsibility is to ensure that people who come here from, perhaps, different and challenging circumstances, where the relationship between the public and the police is not a trusting one, feel welcomed.

"We have to go into those communities and demonstrate that we are worthy of that trust after earning it and also show them respect. Part of showing that respect is getting the information they need in the languages they speak in a way which is culturally competent and respectful of their backgrounds and their faith."

Four years ago, the Toronto Police Service (TPS) created the Community Mobilization Unit's Newcomer Outreach Program to help new immigrants become familiar with the role the police play in Canadian society. Its "Guide to Police Services in Toronto" provides new immigrants with information on police services in Toronto, information on how to access those services, and explains some of their rights and responsibilities under Canadian law.

Translated into 25 languages, the guide is available on an outreach website that includes downloadable video and printable versions of the guide in all 25 languages. It is also available on DVD and at interactive video kiosks.

According to TPS Board chair Alok Mukherjee, this resource tool, funded by Citizenship and Immigration Canada, is an invaluable addition which the organization uses to reach out to all segments of the community.

The creation of the guide was truly a community effort. A total of 38 agencies and organizations serving new immigrants collaborated with the City of Toronto Diversity Management \& Community Engagement in a needs-assessment survey to identify the specific needs of newcomers and the barriers they may face in trying to access police services.

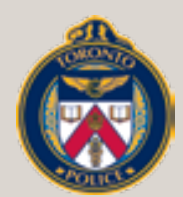

Toronto Police Service

The Toronto Police Service (TPS), formerly the Metropolitan Toronto Police, is the police service for the City of Toronto, Ontario. It is the largest municipal police service in Canada and second largest police force in Canada after the Royal Canadian Mounted Police (RCMP).

Mission: "We are dedicated to delivering police services in partnership with our communities to keep Toronto the best and safest place to be."

www.torontopolice.on.ca 


\section{Deputy Chief Peter Sloly}

Now in his 23rd year with the Toronto Police Service, Deputy Chief Peter Sloly is in charge of Divisional Policing Command. Made

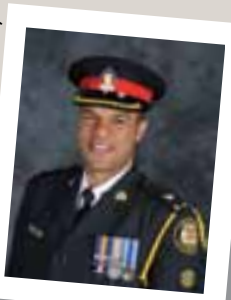
up of 4,084 police officers, 22 I civilian members and a budget of \$447 million, Divisional Command includes the 17 Police Divisions along with the following functions: Toronto Anti-Violence Intervention Strategy (TAVIS), Community Mobilization and Special Events.

Peter is a member of the Ontario Association of Chiefs of Police, the Canadian Association of Chiefs of Police, the International Association of Chiefs of Police, the FBI National Academy Associates, the Police Executive Research Forum, the TPS Military Veterans Association and the Association of Black Law Enforcement Officers.

Prior to his policing career he played professional soccer and was a member of the Canadian National Soccer Team.

\section{Contact information}

\section{Peter Sloly}

Deputy Chief of Police

Divisional Policing Command

Toronto Police Service

40 College Street

Toronto, Ontario, Canada

M5G 2J3

peter.sloly@

torontopolice.on.ca

www.torontopolice.on.ca
To ensure that the guide reaches newcomers in large numbers, it is promoted, among other places, through local schools, community organizations, and local libraries. Liaison officers give presentations to newcomers as well as to community organizations from various ethno-cultural communities.

Finally, the program is also promoted through local ethnic media - television, radio and newspapers.

www.torontopolice.on.ca/communitymobilization/newcomer

\section{Making it work for you}

- Overcome language barriers by involving employees who speak the languages of the communities you are targeting.

- Translate written and audio visual materials to ensure wide accessibility.

- Make materials accessible in many formats, including for viewing and downloading online.

- Work closely with local communities and community organizations that have the necessary cultural knowledge. 


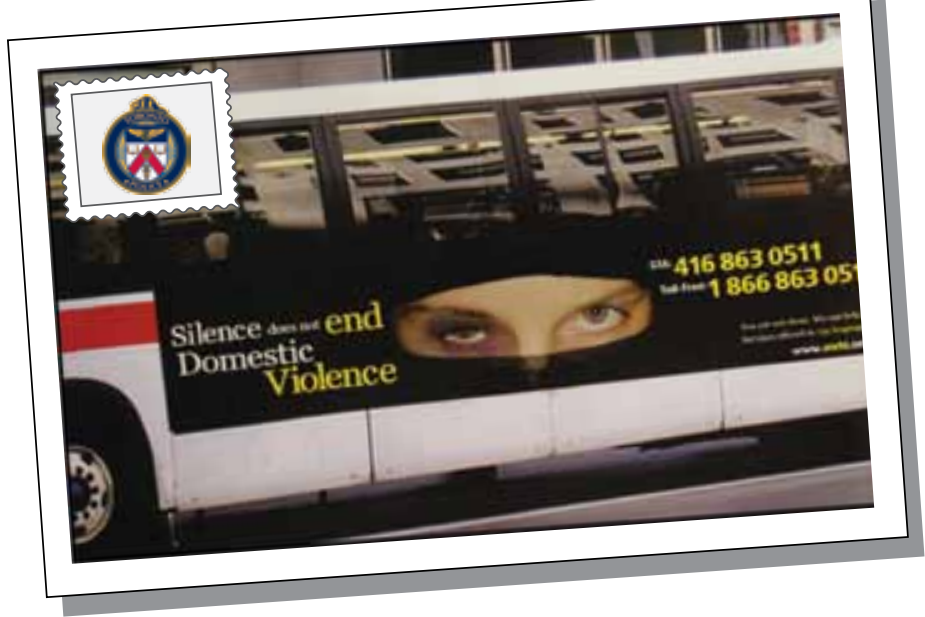

Domestic violence is a very serious issue. On average there are six to ten domestic related homicides each year in the City of Toronto. The TPS responds to approximately 23,000 domestic calls for service each year. Studies indicate that a victim of domestic violence endures 30 to 40 incidents before reporting to the police for the first time. Of even greater concern is the fact that this level of reporting is likely only a small fraction of the actual problem. In the case of victims who come from diverse communities, new to this country and who face access barriers such as language, the level of reporting is even lower.

TPS needed to come up with a strategy to address issues of domestic violence in diverse communities as well as promoting partnerships between police and community agencies to improve confidence and trust in each other, heighten community and public awareness and increase levels of comfort with the reporting process.

Through consultation with community partners who deal with domestic violence, TPS determined that a key strategy to reduce violence among this vulnerable group was to develop education and awareness tools specifically for multicultural victims of violence.

In January 2010, the TPS approached Professor Paul Shecter from Seneca College at York University. Students in his course "Graphic Arts for Social Change" are taught the methodology of producing effective marketing and advertising campaigns focused on a prevailing and current social issue. A new class of 25 students began work to address the issue of domestic violence in diverse communities.
To assist the students in understanding this complex issue and to educate and prepare them for this initiative, Family Violence Unit officers from the Community Mobilization Unit prepared an initial two-hour presentation. This was followed by a seven-week agenda of speakers and materials, including subject matter experts from the community and community liaison police officers.

The involvement of community partners was a critical component in this process. They were able to provide students with a comprehensive understanding of the issues surrounding domestic violence in diverse communities.

In February 2011, five student teams presented the final results at the Toronto Police College. They produced professional quality marketing campaigns to educate and inform diverse communities about domestic violence.

As successful as the collaboration was to this point, it was essential to find the means to deliver this message to the intended audience and get these important messages out to the community. The work of three student teams was selected for further development. They were then asked to enhance their projects with the direct input of the community agencies that serve victims of domestic violence in diverse communities.

www.torontopolice.on.ca/communitymobilization/ domesticviolence

\section{Making it work for you}

- Understand and respect cultural sensitivity - work through any cultural barriers that may restrict the voices of women.

- Magnify the voices of community agency and service providers working with victims of domestic violence. Police officers alone could not have provided the perspective of domestic violence necessary to drive and motivate these students. It is crucial that communities and community groups be heard as well. 


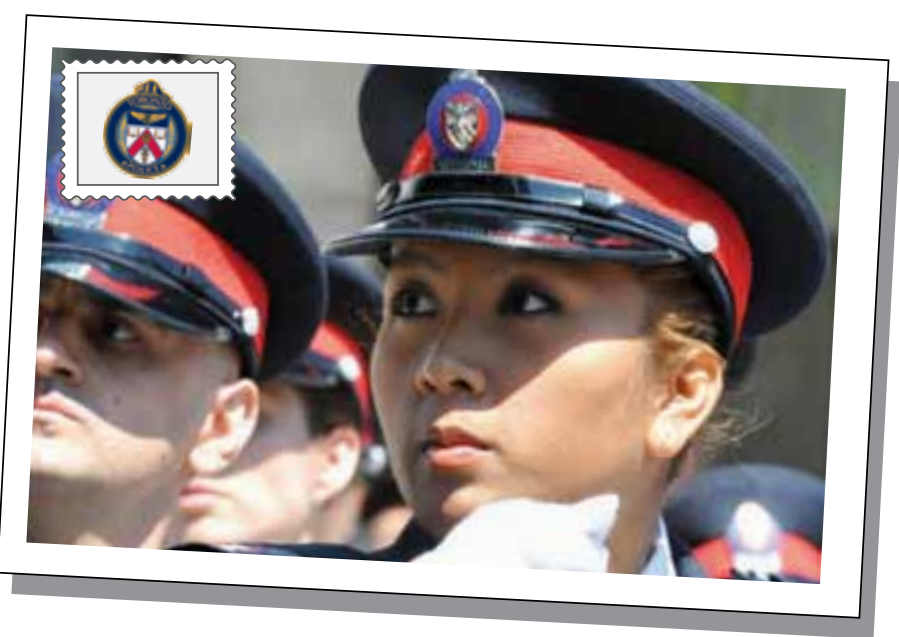

For an organization to be progressive and competitive, it has to be able to attract the brightest and most creative minds. When people bring an array of experience with them to a position, progressive change is never far behind. This is extremely relevant in the policing world, as Toronto is increasingly represented by people from different countries, ethnicities, backgrounds, and experiences. Recognizing the benefits of diversity is an emerging global trend which public and private institutions are beginning to realize. Many police services are also beginning to realize this, and are targeting certain groups in their hiring and recruiting process.

In 2009, newly minted Constable Trisha Barbero did not realize her pursuit of becoming a police officer would break new ground in the city.

She was one of the first three Filipino women to join TPS ranks that year. The trio only found out they would be breaking new ground when they came to apply for the job.

"It's overwhelming," said Barbero, a graduate school student when she applied.

"I was quite surprised we are the first - you don't expect to be a part of history like this."

The 2009 recruit class was, once again, very diverse, made up of $16 \%$ women, $33 \%$ visible minorities and $18 \%$ with previous policing or military experience. A total of $60 \%$ spoke a language other than English, with $22 \%$ speaking two languages other than English, including American Sign Language, Arabic, Bosnian, Cantonese, Croatian, Dutch, Farsi, French, Gujarati, Hebrew, Hindi, Hungarian, Italian, Korean, Macedonian, Mandarin, Polish, Portuguese, Punjabi, Romanian, Russian, Spanish, Tagalog, Tamil,
Teochen, Turkish, Ukranian and Urdu.

The TPS is becoming a leader in increasing diversity of new recruits to build meaningful community partnerships, while also providing first-class policing for the city.

In the face of increased competition, and in order to be a leader in the policing field, the Employment Unit created a new "Recruiting, Hiring, and Customer Relations" strategy. The strategy included an Ambassador Program, a Media \& Communications Plan, a Blended Interview, and an Enhanced Mentoring \& Recruiting plan.

As a result, the TPS has seen an increase in the number of women, visible minorities, Aboriginals, GLBT (Gay, Lesbian, Bisexual, and Transgender) persons, and persons with disabilities applying. There was also an increase of hires that were multilingual, that had obtained post-secondary education, or that had military experience.

As the Employment Unit looks ahead, its greatest challenge is the continuation of programs and initiatives which aim to increase the number of culturally competent candidates applying to the TPS. Currently, the Employment Unit is meeting the set goals mandated by the Human Resources Command and the Staff Planning \& Community Mobilization Unit. To remain effective in policing, the TPS must ensure that there is a dynamic work environment, while being at the leading edge of policing. Sustainable funding must be forthcoming to achieve these goals.

\section{Making it work for you}

- If you want to diversify your workforce, start with a strategy.

- Define hiring target and measure outcomes.

- Support for your diversity strategy needs to come from the top and be funded appropriately. 


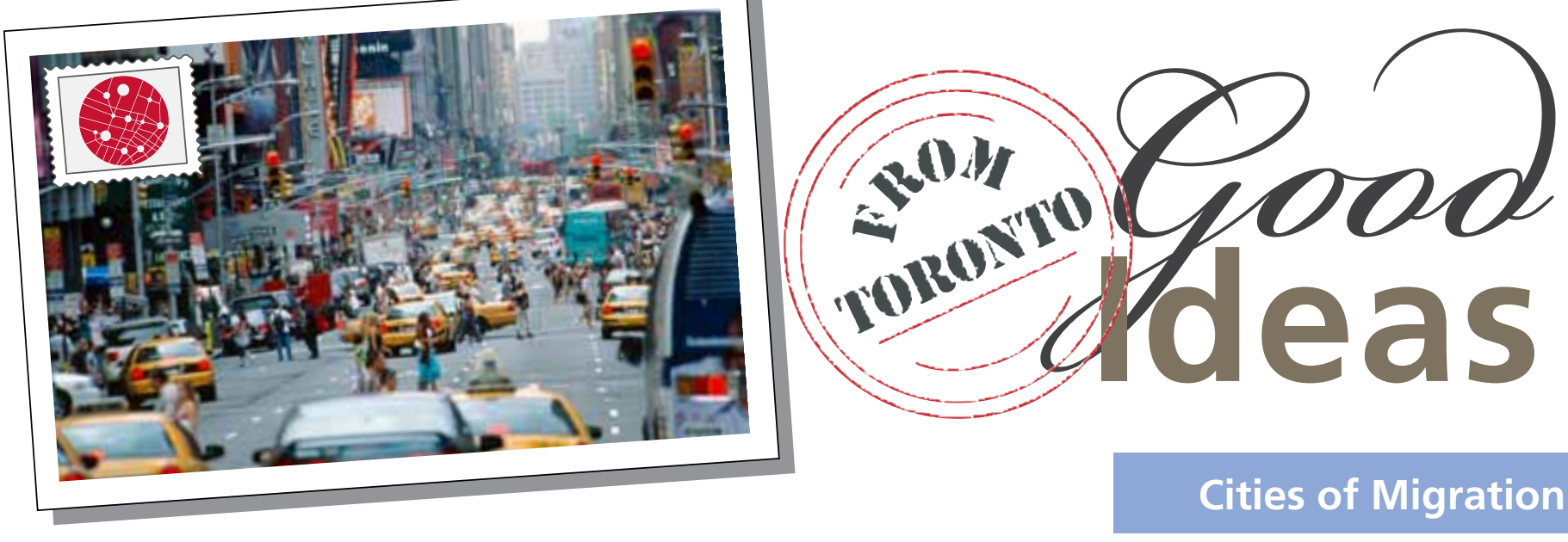

\section{Travelling the World for Good Integration Practices - from Your Desktop}

The previous pages have given you insight into how some of Toronto's most successful organizations contribute to the integration of the city's immigrants. But why stop there? Good integration practices happen in cities across the globe.

Thanks to the Maytree Foundation's Cities of Migration initiative, you now have a place to hear and read about them.

Our online collection of "Good Ideas in Integration" describes practical, tested and ready-to-go initiatives related to immigrant integration from cities around the world. Our international webinars bring together immigration and integration experts and practitioners for city-to-city learning "with no carbon footprint." Good practices, like all good ideas, travel. These unique resources are designed to help cities learn from one another and transfer successful ideas to new cities, new jurisdictions, regions and populations.

Our work at Cities of Migration is more than just about immigration. It's about learning from practice how immigration can result in social, economic, cultural and political benefits to cities, and all city residents, both newcomer and receiving communities. It therefore seems to us that sharing the success of cities as far flung as New York and Berlin, Birmingham, Auckland and Montreal is a simple strategy to enable success to travel from one city to another.

Cities have a critical role to play in integrating newcomers, engaging their residents, and creating opportunities and a sustainable future for all. Regardless of national narratives or policy frameworks, the lived experience of integration is inherently local. The quality of the welcome experienced by immigrants has a huge influence on their future success and ultimately on the prosperity of our cities.

We invite you to become part of the Cities of Migration community. Join us online at www.citiesofmigration.ca as we showcase and discuss good ideas, practical strategies and innovative approaches to framing the policies, managing the messages and implementing the changes that make integration work in today's great global cities.

\section{Ratna Omidvar}

Ratna Omidvar is president of the Maytree Foundation. Under Ratna's leadership, Maytree has been recognized for its commitment to developing, testing and implementing programs and policy solutions related to immigration, integration and diversity in the workplace, in the boardroom and in public office.

Ratna has been appointed to a number of taskforces, including Prime Minister Paul Martin's External Advisory Committee on Cities and Communities. Currently, she is the co-chair of the Mowat Centre Employment Insurance Task Force to examine Canada's support system for the unemployed. Ratna serves as a director of the Greater Toronto CivicAction Alliance, the chair of the Board of Directors of the Toronto Region Immigrant Employment Council (TRIEC), and a director of Connect Legal.

In 2006, she was appointed to the Order of Ontario and, in 2010 , the Globe and Mail, Canada's national newspaper, profiled Ratna as its Nation Builder of the Decade for Citizenship. 


\section{Partner Acknowledgements}

Maytree would like to acknowledge the support of Ambassador Peter M. Boehm and his team at the Canadian Embassy in Berlin for identifying some of the German partners and for sponsoring this publication.

\section{Canadà}

\section{Partners}

\section{STUิㅡGART}

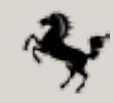

Robert Bosch Stiftung

Körber-stiftung

Forum für Impulse

\section{HEINRICH BÖLL STIFTUNG}

\section{BertelsmannStiftung}

\section{In cooperation with}

Ministry of Labour, Integration and Social Affairs North Rhine-Westfalia

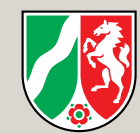

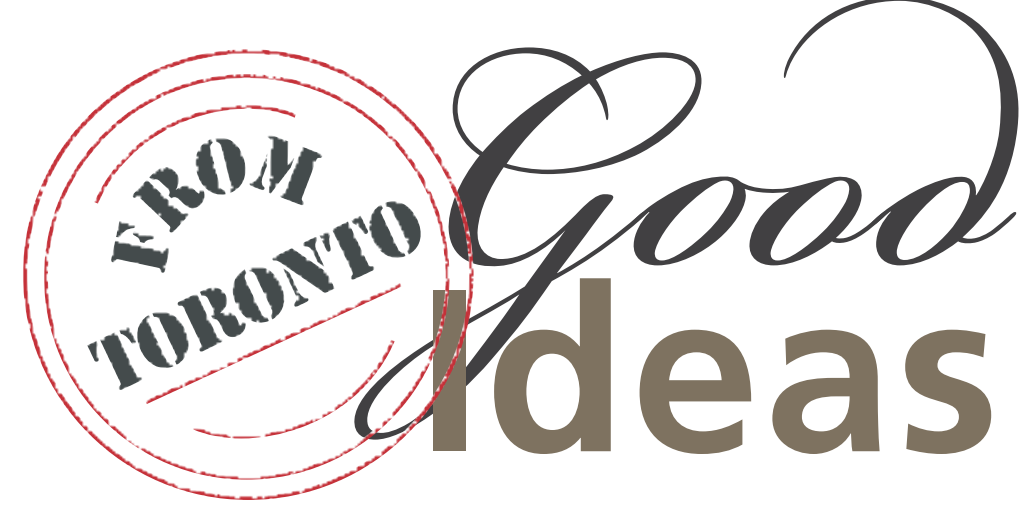

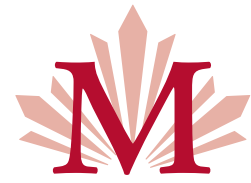

M A Y T R E E

For Leaders. For Change.

\section{Maytree}

Established in 1982, Maytree is a private foundation that promotes equity and prosperity. Its focus is on the reduction of poverty in Canada, with a particular focus on immigration, integration and diversity. The foundation is known for its commitment to developing, testing, and implementing programs and policy solutions related to immigration, integration and diversity in the workplace, the boardroom and public office.

Maytree does this work for sound business reasons. Immigration brings economic and social benefits to Canada's cities, and, in turn, this brings prosperity to the country. The foundation therefore sees its engagement in migration and its attendant issues as a wise investment of private money for public good.

\section{Contact information}

Maytree

170 Bloor Street West, Suite 804

Toronto, Ontario, CANADA M5S 1 T9

Tel: + 1-416.944.2627

Fax: $+1-416.944 .8915$

Email: info@maytree.com

Website: www.maytree.com 


\section{M}

170 Bloor Street West, Suite 804, Toronto, ON M5S 1T9 | 416.944.2627 | www.maytree.com 